\title{
ANTI-INFLAMMATORY AND ANALGESIC ACTIVITIES OF AVOCADO SEED (Persea americana Mill.)
}

\author{
AKTIVITAS ANTIINFLAMASI DAN ANALGESIK BIJI ALPUKAT \\ (Persea americana Mill.)
}

\section{Caecilia Desi Kristanti, Fransisca Puspa Jelita Simanjuntak, Ni Kadek Pramita Anggara Dewi, Skolastika Venita Tianri, Phebe Hendra*)}

Faculty of Pharmacy, Universitas Sanata Dharma, Campus 3 Paingan, Maguwoharjo, Depok, Sleman, Yogyakarta, 55282

Received March 14, 2017; Accepted July 25, 2017

\begin{abstract}
The purpose of this research is to evaluate the anti-inflammatory and analgesic activities of infusion and methanolic extract from avocado seeds. The anti-inflammatory activity was determined using carrageenan-induced paw edema in mice. The analgesic activity was assessed using acetic acid stimuli to induce peripheral pain in mice. Results of this research showed that both all level doses of infusion and methanolic extract of avocado seeds have a significant reduction on the mice paw edema. All level doses of methanolic extract of avocado seeds have a significant reduction on the number of abdominal writhes induced by acetic acid, but only the lowest dose of infusion showed a significant reduction. Our findings suggest that avocado seeds contains potential anti-inflammatory and analgesic compounds which support its traditional use. Further phytochemical studies are required to determine the active compounds are actually responsible for such properties.
\end{abstract}

Keywords: anti-inflammatory, analgesic, infusion, methanolic extract, avocado seeds

\begin{abstract}
ABSTRAK
Penelitian ini bertujuan untuk mengetahui aktivitas antiinflamasi dan analgesik pada infusa dan ekstrak metanol biji alpukat. Aktivitas antiinflamasi ditentukan dengan menggunakan induksi karagenin edema pada mencit. Aktivitas analgesik dievaluasi menggunakan rangsang asam asetat yang menginduksi nyeri perifer pada mencit. Hasil penelitian menunjukkan bahwa pada semua peringkat dosis baik infusa dan ekstrak metanol biji alpukat menunjukkan penghambatan edema yang bermakna pada edema mencit. Semua peringkat dosis ekstrak metanol biji alpukat menunjukkan penurunan geliat akibat induksi asam asetat, namun hanya dosis terendah infusa biji alpukat yang mampu menurunkan jumlah geliat. Berdasarkan hal tersebut, maka biji alpukat mengandung senyawa yang berpotensi sebagai antiinflamasi dan analgesik. Penelitian fitokimia lanjutan diperlukan untuk mengetahui kandungan senyawa biji alpukat yang bertanggung jawab terhadap aktivitas antiinflamasi dan analgesik.
\end{abstract}

Kata kunci: antiinflamasi, analgesik, infusa, ekstrak metanol, biji alpukat 


\section{INTRODUCTION}

Inflammation is a protective response purposely to get rid of organism that causes injury (e.g. microbes and toxins) and the consequence of the injury (e.g. the damage of cell and tissue). Without inflammation, infection will continue developing, wounds will not heal, and the injured organ will continue suppurating. In the process of inflammation, there is a process in which free radical compounds are generated (Ardhie, 2011). Free radicals can cause tissue decay that triggers biosynthesis of arachidonic acid into prostaglandin as the mediator of inflammation (Sanchez et al., 2015). Excessive inflammatory responses or severe tissue decay should be handled immediately, thus inflammatory reaction should be treated to reduce signs and symptoms (Meliala and Pinzon, 2007). General symptoms of inflammation such as swelling, heat, pain, redness, and the loss of function can cause discomfort for the patient so that it needs to be handled (Supriyatna et al., 2015). In that case, anti-inflammatory compounds and analgesic compounds are needed.

Arukwe et al. (2012) reported that avocado seeds contain chemical compounds such as alkaloid, glycoside, fennel, steroid, tannin, flavonoid, and saponin. Research by Malangngi et al. (2012) shows an antioxidants of avocado seed ethanol extract with DPPH method. Antioxidant compounds play role in detaining inflammation with the mechanism of capturing free radicals and detaining cyclooxygenase enzyme to hold up the occurrence of prostaglandin. This will impact in the inhibiton of inflammatory mediators. This thing is in accordance to the research that shows the existence of analgesic activity from avocado seed ethanol extract (Kyakulaga et al., 2012).

Josephine and Ngozi (2013) reports the existence of analgesic activity from avocado seed juice. From the research by Hendra et al. (2014), infusion and decocta of avocado seed has protective effect to livers and kidneys of mice induced with carbon tetrachloride, that was indicated by the effect of antioxidant activity in avocado seed. Infusion is a simple preparation that is commonly used in the making of traditional medicine and is easy to be applied by Indonesian society. However, the research of analgesic and antiinflammation activity of avocado seed infusion is never reported, although there is a polar similarity between ethanol and methanol. Based on those things, the research objective is to find out the anti-inflammation and analgesic activity in both infusion and avocado seed methanolic extract on mice.

\section{METHODS \\ Materials}

Materials used in this research is a Swiss mice, avocado seeds, distilled water, methanol, carrageenan 1\%, Cataflam Fast ${ }^{\circledR} 50$ mg (Novartis Ltd.), aspirin (E. Merck), glacial acetic acid (E. Merck), $\mathrm{NaCl} 0.9 \%, \mathrm{CMC}-\mathrm{Na}$ $1 \%$. The experimental protocols were approved by The Medical and Health Research Ethics Committee (MHREC) Fac. of Medicine Gadjah Mada University with reference number KE/FK/964/EC/2016.

\section{Preparation of Avocado Seed}

Avocado seeds were collected from an iced drink stall on June and undergone a plant determination. Collected avocado seeds were then wet sorted, washed with flowing water, and minced to pieces with $\pm 2 \mathrm{~mm}$ thickness. The seeds were then dried using an oven in $50^{\circ} \mathrm{C}$, and then powdered using a powdering machine and strained using a strainer with mesh number 40/50. Avocado seed powder was then undergone a water content measurement.

\section{Preparation of Avocado Seed Infusion}

Avocado seed dry powder was measured to $\pm 8 \mathrm{~g}$, and then put into infusion pan and dampened with $16 \mathrm{~mL}$ distilled water. Afterwards $100 \mathrm{~mL}$ distilled water solvent was added to the mixture of powder and distilled water, which then heated using water heater to $90^{\circ} \mathrm{C}$ for 15 minutes. The mixture was then squeezed using flannel cloth. Hot distilled water was added to result $100 \mathrm{~mL}$ of avocado seed infusion (Hendra et al., 2014). 


\section{Avocado Seed Methanolic Extract Preparation}

An amount of $200 \mathrm{~g}$ simplicia powder was divided into 8 Erlenmeyer flasks and soaked with $200 \mathrm{~mL}$ methanol $90 \%$. The mixture was then undergone a maceration for 72 hours. Maceration result was then moved into Erlenmeyer flasks and then the macerated for 48 hours. The macerated result was then strained using Buchner funnel and then evaporated using rotary evaporator for 2 hours. Extract was then moved into a porcelain dish and scaled. The extract was then evaporated above a water bath and heated inside an oven in $50^{\circ} \mathrm{C}$ to get the fixed weight and resulted in a condensed extract with $19.61 \%$ yield. The making of test solution was done by dissolving the condensed extract with CMC-Na $1 \%$ and producing $10 \%$ of test solution concentrate.

\section{Avocado Seed Anti-Inflammatory Activity Test}

Forty-five male mice were randomly divided into 9 groups. Group I and II as the negative control was given respectively distilled water and $\mathrm{CMC}-\mathrm{Na}$, group III as positive control was given Cataflam Fast ${ }^{\circledR} 4.48$ $\mathrm{mg} / \mathrm{kgBW}$, group IV-VI were given avocado seed infusion with three levels of doses respectively $0.67 ; 1.33$; and $2.67 \mathrm{~g} / \mathrm{kgBW}$, group VII-IX were given avocado seed methanolic extract with three doses levels respectively $0.83 ; 1.67 ; 3.33 \mathrm{~g} / \mathrm{kgBW}$. All of the compounds were given orally to the mice and after 15 minutes, carrageenan $1 \%$ was injected with subplantar. The measurement of anti-inflammatory activity was done by measuring mice's paw edema using calipers from minute $0,15,30,45,60,90,120,150$, $180,210,240,270,300,330,360$ after induced by carrageenan $1 \%$ (Tjandrawinata et al., 2015; Hendra et al., 2017). Edema value was measured by the Area Under Curve (AUC) from the thickness of carrageenan induced mice paw edema of each treatment in every time range of the measurement with trapezoid method. Measurement formula is as follows:
$\mathrm{AUC}_{0-\mathrm{x}}=\left(\frac{C 1-C 0 \times}{2} \times \mathrm{t}_{1}-\mathrm{t}_{0}\right)+\left(\frac{C 2-C 1}{2} \times \mathrm{t}_{2}-\mathrm{t}_{1}\right)+\ldots+\left(\frac{C n-C n-1}{2} \times \mathrm{t}_{\mathrm{n}}-\mathrm{t}_{\mathrm{n}-1}\right)$

Note :

$\mathrm{AUC}_{0-\mathrm{x}}=$ Area Under Curve from edema thickness on mice's paws on minute 0 to minute 360 .

$\mathrm{C}_{\mathrm{n}}-\mathrm{C}_{\mathrm{n}-1}=$ The thickness of edema from minute 0 to minute 360 .

$t_{n}-t_{n-1}=$ The length of measurement time from minute 0 to minute 360 .

Anti-inflammatory activity could be seen from the percentage of inhibition of inflammation and is measured using the following formula:

Inhibition of inflammation $(\%)=\underline{(A U C 0 \cdot x) 0 \cdot(A U C 0 \cdot x) n} \times 100 \%$ $(A U C 0-x) 0$

Note :

$\left(\mathrm{AUC}_{0-\mathrm{x}}\right)_{0}=\mathrm{AUC}_{0-\mathrm{x}}$ median from mice's paw edema thickness to the negative control group (mm.minute).

$\left(\mathrm{AUC}_{0-\mathrm{x}}\right)_{\mathrm{n}}=\mathrm{AUC}_{0-\mathrm{x}}$ total from $\mathrm{AUC}$ mice's paw edema thickness that were given test solution with doses $\mathrm{n}$ (mm.minute).

\section{Testing Avocado Seed Analgesic Activity}

Forty female mice were divided into eight treatment groups. Group $\mathrm{I}$ as the negative control was given CMC-Na. Group II, as the positive control, was given acetosal $1 \%$ with doses of $0.091 \mathrm{~g} / \mathrm{kgBW}$. Group III-V respectively was given avocado seed methanolic extract with doses of $0.67 ; 1.33$ and $2.67 \mathrm{~g} / \mathrm{kgBW}$ while group VI-VIII was given avocado seed methanolic extract with three doses level respectively $0.83 ; 1.67 ; 3.33$ $\mathrm{g} / \mathrm{kgBW}$. All of the treatments were given orally, and then after 10 minutes were given acetate acid $1 \%$ doses $50 \mathrm{mg} / \mathrm{kgBW}$ intraperitoneal (i.p). The data of the number of writhes obtained from the analgesic test result was analyzed by counting the protection percentage using the following equation:

$$
\% \text { protection }=(100-(\mathrm{P} / \mathrm{K} \times 100)) \%
$$

Note:

$\mathrm{P}=$ Cumulative number of test animals' writhes after given test compound.

$\mathrm{K}=$ Median of cumulative number of negative control test animals' writhes after given test compound. 


\section{Statistical Analysis}

The result was analyzed using Shapiro Wilk test to obtain the number of data distribution. According to the test, it was seen that every group has normal distribution $(\mathrm{p}>0.05)$. Afterwards, variant test was conducted and it resulted probability value as much as 0.405 ( $\mathrm{p}>0.05)$ which showed that the data variant that was tested was the same. It was continued with one-way ANOVA test with $95 \%$ trust level, which obtained probability value as much as 0.000 (p.0.05) which showed that at least there was total AUC median that was significant in the two groups. Afterwards, Post Hoc analysis was conducted using LSD test.

\section{RESULTS AND DISCUSSION}

In this research was avocado seed powder in the form of infusion and methanolic extract were used. Plant determination was done in Phytochemistry and Pharmacology Laboratory of Sanata Dharma University using the web of Agriculture \& Natural Resources University of California. Based on the determination result, the tested plant was indeed Persea americana Mill. The result of the water content test showed average water content as $8.17 \% \mathrm{~b} / \mathrm{b}$. This showed that the avocado seed powder met the requirements as good quality powder.

\section{Avocado Seed Anti-Inflammatory Activity Test Result}

Method used to determine antiinflammatory activity in this research was induction method towards the mice's paw edema using carrageenan $1 \%$. This method was used because it is simple and easy to conduct, while the measurement of the edema is accurate and objective. Carrageenan was used because it can induce inflammation reaction which is acute and non-immunologic. Carrageenan can be well observed and has high reproducibility (Moris, 2003). Edema measurement can be done repeatedly so that a more accurate data can be obtained.

Avocado seed anti-inflammatory activities, both infusion and methanolic extract, were shown through the decreasing thickness of paw edema on the test animals' paws on each time unit after the treatment of carrageenan $1 \%$ that was shown from the decrease on total AUC value and also the percentage inhibition of inflammation (PI) from each treatment group through negative control (Table I). Compound is declared as having anti-inflammatory activity if the median of total AUC is low and significantly different with the negative control.

In the positive control group, the test animals were orally given Cataflam Fast $^{\circledR}$ (diclofenac $4.48 \mathrm{mg} / \mathrm{kg} \mathrm{BW}$ ), and showed AUC median as $206.90 \mathrm{~mm}$.minute with percentage inhibition of inflammation as $51 \%$ which was significantly different $(\mathrm{p}<0.05)$, compared to distilled water negative control or CMC-Na. This showed that diclofenac 4.48 $\mathrm{mg} / \mathrm{kgBW}$ can inhibit inflammation in mice's paws generated from carrageenan induction.

Avocado seed infusion treatment groups 0.67; 1.33 and $2.67 \mathrm{~g} / \mathrm{kgBW}$ showed different AUC median which was significantly different $(p<0.05)$ from negative control distilled water group. This shows that giving avocado seed infusion to three doses levels give antiinflammatory activity. Avocado seed infusion $0.67 \mathrm{~g} / \mathrm{kgBW}$ had AUC value which was insignificantly different ( $p>0.05$ ) compared to diclofenac positive control which showed that anti-inflammatory activities of the two groups were relatively the same. Avocado seed infusion 1.35 and $2.67 \mathrm{~g} / \mathrm{kgBW}$ had larger significant AUC value compared to diclofenac postive control. This shows the infusion treatment 1.33 and $2.67 \mathrm{~g} / \mathrm{kgBW}$ has lower anti-inflammatory activity compared to the group which was treated with dicloflenac.

AUC value of the three doses levels of avocado seed methanolic extract $(0.83 ; 1.67$ and $3.33 \mathrm{~g} / \mathrm{kgBW}$ ) were significantly different $(\mathrm{p}<0.05)$ compared to negative group CMC$\mathrm{Na}$. This shows that the three extract doses have anti-inflammatory activity. Avocado seed methanolic extract 0.83 and $1.67 \mathrm{~g} / \mathrm{kgBW}$ showed AUC value which were significantly larger compared to the diclofenac positive control. This means the anti-inflammatory activity of the two doses levels were lower than the diclofenac positive control. Anti- 
inflammatory activity of the avocado seed methanolic extract $3.33 \mathrm{~g} / \mathrm{kgBW}$ were relatively similar to diclofenac, shown from the insignificantly different AUC value $(\mathrm{p}>0.05)$. The increase of doses in the avocado seed methanolic extract was not followed by the increase of anti-inflammatory activity. This is probably because antioxidant compound extracted was relatively the same to doses $3.33 \mathrm{~g} / \mathrm{kgBW}$.

Table I. AUC value and percentage inhibition of inflammation towards mice treated with avocado seed $(n=5)$

\begin{tabular}{lcc}
\hline Group & Total AUC (mm.minute) & PI (\%) \\
\hline Distilled water negative control & $422.22 \pm 18.75^{\mathrm{b}}$ & $0.00 \pm 4.45$ \\
\hline CMC-Na negative control & $390.62 \pm 22.03^{\mathrm{b}}$ & $0.000 \pm 5.64$ \\
\hline Diklofenac positive control $4.48 \mathrm{mg} / \mathrm{kg} \mathrm{BW}$ & $206.90 \pm 14.59^{\mathrm{a}, \mathrm{c}}$ & $51.00 \pm 3.46$ \\
\hline Avocado seeds infusion 0.67 g/kg BW & $191.03 \pm 14.02^{\mathrm{a}}$ & $54.76 \pm 3.32$ \\
\hline Avocado seeds infusion $1.33 \mathrm{~g} / \mathrm{kg} \mathrm{BW}$ & $281.86 \pm 9.52^{\mathrm{a}, \mathrm{b}}$ & $33.24 \pm 2.25$ \\
\hline Avocado seeds infusion $2.67 \mathrm{~g} / \mathrm{kg} \mathrm{BW}$ & $329.77 \pm 6.86^{\mathrm{a}, \mathrm{b}}$ & $21.90 \pm 1.62$ \\
\hline Avocado seeds methanolic extract 0.83 g/kg BW & $298.29 \pm 16.14^{\mathrm{c}, \mathrm{b}}$ & $23.64 \pm 4.13$ \\
\hline Avocado seeds methanolic extract $1.67 \mathrm{~g} / \mathrm{kg} \mathrm{BB}$ & $258.35 \pm 13.06^{\mathrm{c}, \mathrm{b}}$ & $33.86 \pm 3.34$ \\
\hline Avocado seeds methanolic extract $3.33 \mathrm{~g} / \mathrm{kg} \mathrm{BB}$ & $241.93 \pm 13.72^{\mathrm{c}}$ & $43.36 \pm 2.24$ \\
\hline Note: & &
\end{tabular}

Note:
AUC value and PI was presented in the form of median \pm error standard
$\mathrm{a}=$ significant difference towards distilled water negative control $(\mathrm{p}<0.05)$
$\mathrm{b}=$ significant difference towards positive control $(\mathrm{p}<0.05)$
$\mathrm{c}=$ significant difference towards negative control $\mathrm{CMC}-\mathrm{Na}(\mathrm{p}<0.05)$
$\mathrm{PI}=$ percentage inhibition of inflammation

Table II. Writhes and avocado seed protection percentage on mice $(\mathrm{n}=5)$

\begin{tabular}{|c|c|c|}
\hline Test Group & Writhes & $\begin{array}{c}\text { Protection Percentage } \\
(\%)\end{array}$ \\
\hline Negative Control CMC-Na & $74.0 \pm 0.5^{\mathrm{b}}$ & $0.0 \pm 0.6$ \\
\hline Acetosal Positive Control & $19.8 \pm 0.4^{\mathrm{a}}$ & $73.2 \pm 0.5$ \\
\hline Avocado seed infusion $0.67 \mathrm{~g} / \mathrm{kg} \mathrm{BW}$ & $19.0 \pm 1.1^{\mathrm{a}}$ & $74.3 \pm 1.5$ \\
\hline Avocado seed infusion $1.33 \mathrm{~g} / \mathrm{kg} \mathrm{BW}$ & $54.2 \pm 3.8^{\mathrm{b}}$ & $26.8 \pm 5.1$ \\
\hline Avocado seed infusion $2.67 \mathrm{~g} / \mathrm{kg} \mathrm{BW}$ & $71.8 \pm 1.3^{\mathrm{b}}$ & $3.0 \pm 2.1$ \\
\hline Avocado seeds methanolic extract $0.83 \mathrm{~g} / \mathrm{kg} \mathrm{BW}$ & $46.2 \pm 1.5^{\mathrm{a}, \mathrm{b}}$ & $37.6 \pm 2.0$ \\
\hline Avocado seeds methanolic extract $1.67 \mathrm{~g} / \mathrm{kg} \mathrm{BW}$ & $19.8 \pm 1.1^{\mathrm{a}}$ & $73.2 \pm 1.4$ \\
\hline Avocado seeds methanolic extract $3.33 \mathrm{~g} / \mathrm{kg} \mathrm{BW}$ & $23.2 \pm 0.7^{\mathrm{a}}$ & $68.2 \pm 0.9$ \\
\hline
\end{tabular}

Note:

The number of writhes and protection percentage presented in the form of medianterror standard $\mathrm{a}=$ significant difference towards negative control CMC-Na $(\mathrm{p}<0.05)$

$\mathrm{b}=$ significant difference towards positive control $(\mathrm{p}<0.05)$ 


\section{Avocado Seed Analgesic Activity Test Result}

Analgesic activity test in this research used chemical stimulation method using acetate acid $1 \%$ as the pain induction compound. Acetate acid triggers the release of arachidonate from phospholipid tissue. COX enzyme will change arachidonate acid into prostaglandin which will stimulate inflammation and pain. The mice show pain response with writhes (Muhammad, 2014). The number of writhes and protection percentage as well as avocado seed methanolic extract are presented on Table II.

Anonymous (1991) states that there is an analgesic activity to the chemical stimulation method shown by the reduction of writhing $\geq$ $50 \%$ compared to the negative control groups. Mean of writhes of positive control acetosal (19.8) was significantly different compared to negative control CMC-Na. This showed that acetosal can give analgesic activity to mice induced with acetate acid with percentage inhibition of pain as $73.2 \%$.

In the treatment of the three avocado seed infusion doses, only $0.67 \mathrm{~g} / \mathrm{kgBW}$ that gave significant difference of writhes $(\mathrm{p}<0.05)$ compared to negative control. This means only avocado seed infusion $0.67 \mathrm{~g} / \mathrm{kgBW}$ that has protection ability towards acetate acid. This shows avocado seed infusion $0.67 \mathrm{~g} / \mathrm{kgBW}$ as having analgesic activity. This research result is in accordance with research reported by Josephine and Ngozi (2013) which shows analgesic activity in avocado seed juice.

Mean of writhes of methanolic extract of avocado seed doses $0.83 ; 1.67$ and 3.33 $\mathrm{g} / \mathrm{kgBW}$ were significantly different $(\mathrm{p}<0.05)$ compared to negative group CMC-Na. This showed that the three levels of extract doses have ability in reduction of writhing on mice induced with acetate acid. According to Anonymous (1991), only avocado seed methanolic extract doses 1.67 and 3.33 $\mathrm{g} / \mathrm{kgBW}$ which show analgesic activity because they show percentage inhibition of pain to $>50 \%$, respectively $73.2 \%$ and $68.2 \%$. The two doses levels have analgesic activities which are comparable with acetosal control. This result is similar to the research reported by Kyakulaga et al. (2012) that shows that avocado seed ethanol extract has analgesic activity. This show that organic extracts, both methanol and ethanol, can attract compounds that give analgesic activity.

The increase of avocado seeds infuse doses is not in accordance with the increase of activity, both anti-inflammatory and analgesic. This is shown by the fact that although the doses were increased, both the percentage inhibition of inflammation and percentage inhibition of pain were decreased. This thing allegedly was due to the change of antioxidant property into pro-oxidant property within the compounds contained in the avocado seeds. In the in vitro test, it was reported that antioxidants such as high doses flavonoid could stimulate Reactive Oxygen Species (ROS) through auto-oxidation (myricetin and quercetagetin) and redox-cycling (quercetin) (Bouayed and Bohn, 2010). Thus, phytochemistry test should be done to the compounds contained within high doses avocado seed infusion. Other probability is saturation within the pain receptor, so that the increase of doses was not followed by the increase of activity.

Both the carrageenan induced mice's ability to inhibit inflammation and acetate acid induced mice's ability to protect itself from pain which were obtained from Persea americana Mill. Seed infusion and methanolic extract were related with the existence of flavonoid compounds. Prochazkova et al. (2011) reported that flavonoid is a compound that can capture free radicals which results in inflammation and antioxidant reaction. Avocado seeds have relatively high antioxidant activity so that it can be considered as one of natural antioxidant sources (Malangngi, 2012). According to Arukwe et al. (2012) and Gomez et al. (2014), avocado seeds are rich in flavonoid, which shows radical capturing activity towards DPPH (Konsinska et al., 2012). Flavonoid plays the role as ROS through its reaction towards reactive compounds and free radicals which cause inactivity in damaged cell tissue. 


\section{CONCLUSION}

Infusion $0.67 \mathrm{~g} / \mathrm{kgBW}$ and methanolic extract $3.33 \mathrm{~g} / \mathrm{kgBW}$ of Persea americana Mill. (avocado) seeds has anti-inflammatory activity towards carrageenan induced mice. Infusion $0.67 \mathrm{~g} / \mathrm{kgBW}$ and methanolic extract 1.67 and $3.33 \mathrm{~g} / \mathrm{kgBW}$ of Persea americana Mill. (avocado) seeds has analgesic activity towards acetate acid induced mice.

\section{REFERENCES}

Anonymous, 1991. Analgestika. In: Yayasan Pengembangan Obat Bahan Alam Phyto MedikaPedoman Pengujian dan Pengembangan Fitofarmaka, Penapisan Farmakologi, Pengujian Fitokimia dan Pengujian Klinik. Departemen Kesehatan RI. Jakarta, 3-5.

Ardhie, A. M., 2011. Radikal Bebas dan Peran Antioksidan dalam Mencegah Penuaan. Medicinus, 24(1), 4-9.

Arukwe, U., Amadi, B., Duru M., Agomuo, E., Adindu, E., Odika, P., Lele, K.C., Egejuru, L., Anudike, J., 2012. Chemical Composition of Persea americana Leaf, Fuit and Seed. IJRRAS, 11 (2), 346-349.

Bouayed, J., Bohn, T., 2010. Exogenous Antioxidants-Double Edged Swords in Cellular Redox State. Oxidative Medicine and Cellular Longevity, 3(4), 228-237.

Chaulya NC, Haldar PK, Mukherjee A., 2012. Anti-inflammatory and Analgesic Activity of Methanolic extracts of Cyperus tegetum Roxb. Rhizome. Journal of PharmaSciTech, 1(2), 27-9.

Gomez, F.S., Sanchez, S.P., Iradi, M.G.G., Azman, N.A.M., Almajano, M.P., 2014. Avocado Seeds: Extraction Optimization and Possible Use as Antioxidant in Food. Antioxidants, 3, 439-454.

Hendra, P., Krisnadi, G., Perwita, N.L.P.D., Kumalasari, I., Quraisyin, Y.A., 2014. Efek Hepatoprotektif dan Nefroprotektif Biji Alpukat pada Tikus Terinduksi Karbon Tetraklorida. Tradisional Medicine Journal, 19(3), 133-137.

Hendra, P., Fenty, Andreani, P.R., Pangestuti, B.M.E., Julianus, J., 2017. Evaluation of Antihyperlipidemic, Anti-inflammatory, and Analgesic Activities of Eurycoma longifolia in Animal Models. Int $J$ Pharm Pharm Sci., 9(3), 166-169.

Joshepine, O.O., Ngozi, A.O., 2013. Analgesic Effect of The Aqueous Extract of Persea americana Mill (Lauraceae). Journal of Pharmaceutical and Allied Sciences, 10(3), 1887-1897.

Konsinska, A., Karamec, M., Estrella, I., Hernandez, T., Bartolome, B., Dykes, G.A., 2012. Phenolic Compound Profiles and Antioxidant Capacity of Persea americana Mill. Peels and Seeds of Two Varieties. J. of Agric. Food Chem., 60, 4613-4619.

Kyakulaga, AI.,H., Ogwang, P.E., Nannyonga, S., Nyafuono, J., Tumuslime, R., 2012. Antipyretic and Analgesics Activities of Ethanolic Extract of Persea americana Mill. Seeds in Wistar Albino Rats. Africa Journal of Animal and Biomedical Sciences, 7(1), 19-23.

Malangngi, L.P., Sangi, M.S., Paendong J.J.E., 2012. Penentuan Kandungan Tanin dan Uji Aktivitas Antioksidan Ekstrak Biji Buah Alpukat (Persea americana Mill.). Jurnal Kimia FMIPA Unsrat, 1(1), 5-10.

Meliala, L., Pinzon, R., 2007. Breakthrough in Management of Acute Pain. Dexa Media Jurnal Kedokteran dan Farmasi, 4(20), 151-155.

Morris, C.J., 2003. Carragenan Induced Paw Edema in The Rat and Mouse Inflamation Protocols. Method in Molecular Biology, 2, 115-122.

Muhammad, N., 2014. In Vivo Models for Management of Pain. Scientific Research, 5(1), 92-96.

Prochazkova, D., Bousova, I., Wilhelmova, N., 2011. Antioxidant and Prooxidant Properties of Flavonoids. Fitoterapia, 82, 513-523.

Sanchez, A., Calpena, A.C., Clares, 2015. Evaluating the Oxidative Stress in Inflammation: Role of Melatonin. International Journal of Molecular Sciences, 16, 16981-17004.

Supriyatna, Febriyanti, R., Dewanto, Wijaya, I., Ferdiansyah, F., 2015. Fitoterapi 
Sistem Organ: Pandangan Dunia Barat terhadap Obat Herbal Global.

Tjandrawinata R.R., Djunarko, I., Fenty, Hendra P., 2015. Anti-inflammation
Effects of Bioactive Fraction DLBS0533 Containing Phaleria macrocarpa and Nigellia sativa on Animal Model. In $J$ Pharm Pharm Sci., 7(1), 408-411. 